\title{
Hydrogen sulfide ameliorates isoflurane-induced cognitive impairment in mice: Implication of caspase-3 activation
}

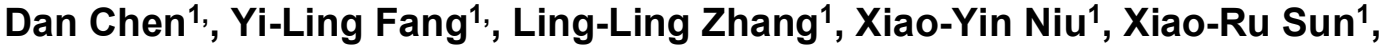 \\ Xiao-Zhen Niu', Xuan Zhao', Cheng Li, ${ }^{1}{ }^{1}$ \\ ${ }^{1}$ Department of Anesthesiology, Shanghai Tenth People's Hospital, Tongji University School of Medicine, Shanghai, P.R. \\ China, ${ }^{2}$ Anesthesia and Brain Research Institute, Tongji University School of Medicine, Shanghai, P.R. China
}

*For correspondence: Email: chengli0903@163.com: Tel: +86-13214171828

Sent for review: 23 Feb 2020

Revised accepted: 26 Mar 2020

\begin{abstract}
Purpose: Isoflurane could induce cognitive impairment and activate caspase-3. However, the mechanism of action is unclear and target interventions are unavailable. The present study examined the potential protective function of hydrogen sulfide $\left(\mathrm{H}_{2} \mathrm{~S}\right)$ against isoflurane-induced cognitive impairment.

Methods: Effects of $\mathrm{NaHS}(5 \mathrm{mg} / \mathrm{kg})$ on cognitive impairment induced by isoflurane $(1.4 \%$ for $2 \mathrm{~h})$ were assessed using a fear-conditioning test in a group of 8-month old mice. H4 human neuroglioma cells, which were transfected with upregulated human amyloid precursor protein were treated for 3 or $6 \mathrm{~h}$ with $2 \%$ isoflurane, in the presence of 100- $\mu \mathrm{M} \mathrm{NaHS}$ in the mice. A group of mice treated with normal saline in place of the NaHS in each case served as control. Western blotting, fluorescence assay, and a mitochondrial swelling assay were employed to observe the results of caspase-3 activation, mitochondrial dysfunction, and ROS and ATP levels.

Results: NaHS significantly mitigated isoflurane-induced cognitive impairment in mice. In cultured cells, $\mathrm{NaHS}$ reduced caspase-3 activation, ROS, mitochondria membrane reduction, mitochondrial permeability transition pore opening, and cellular ATP level. NaHS could ameliorate cognitive impariment induced by isoflurane through inhibiting caspase-3 activation, oxidative stress, and mitochondrial dysfunction.

Conclusion: These results indicate that hydrogen sulfide $\left(\mathrm{H}_{2} \mathrm{~S}\right)$ has potential protective function against isoflurane-induced cognitive impairment. Further investigation of NaHS as an intervention to attenuate anesthesia-associated neurotoxicity is vital.

Keywords: Hydrogen sulfide, isoflurane-cognition, fear conditioning, neurotoxicity
\end{abstract}

\begin{abstract}
This is an Open Access article that uses a fund-ing model which does not charge readers or their institutions for access and distributed under the terms of the Creative Commons Attribution License (http://creativecommons.org/licenses/by/4.0) and the Budapest Open Access Initiative (http://www.budapestopenaccessinitiative.org/read), which permit unrestricted use, distribution, and reproduction in any medium, provided the original work is properly credited.
\end{abstract}

Tropical Journal of Pharmaceutical Research is indexed by Science Citation Index (SciSearch), Scopus, International Pharmaceutical Abstract, Chemical Abstracts, Embase, Index Copernicus, EBSCO, African Index Medicus, JournalSeek, Journal Citation Reports/Science Edition, Directory of Open Access Journals (DOAJ), African Journal Online, Bioline International, Open-J-Gate and Pharmacy Abstracts

\section{INTRODUCTION}

Alzheimer's disease (AD) is a prevailing reason for dementia in adults [1]. Symptoms typically start at age of 60 years and might involve memory loss, failure in performing daily activities, and personality change. The evidence so far shows that exposure to general anesthetics could interact with $A D$-associated pathological mechanisms, and promote the progression of $A D$ [2]. 
A randomized controlled trial showed that sevoflurane could accelerate the progression of cognitive impairment, which often precedes $A D$ [3]. A case-control study in China established that anesthesia during surgery is associated with the risk of dementia [4]. Another study indicated that people in the middle age without cognitive impairment are more likely to have rapid cognitive decline after surgery and anesthesia [5]. Several other studies, however, failed to establish this association in anesthesia and dementia [6-8]. It was previously reported that isoflurane might promote caspase- 3 activation [9], increase amyloid beta-protein $(A \beta)$ level in the brain [10-12], and impair learning and memory [13]. The mechanism on how isoflurane enhances caspase activation is not completely understood, but may result from increased levels of ROS, mitochondrial dysfunction and decreased ATP level [14,15].

In addition to being a gaseous neuromodulator, $\mathrm{H}_{2} \mathrm{~S}$ is also an anti-oxidant and could produce anti-apoptotic effects in neurons and glial cells [16-23]. Accumulating evidence indicates the protective functions of $\mathrm{H}_{2} \mathrm{~S}$ in the CNS in the process of $A D$, vascular dementia, and Parkinson's disease [24-27].

In this study, we hypothesized that sodium hydrosulfide (NaHS) might inhibit caspase-3 activation via ROS-, mitochondria-, and ATPassociated mechanisms in glioma cells transfected with amyloid precursor. Therefore, the purpose of this study was to explore the underlying mechanisms of caspase-3 activation in vitro and examine the potential effect of $\mathrm{NaHS}$ on cognitive impairment in isoflurane-induced mice model.

\section{EXPERIMENTAL}

\section{In vivo Experiments}

Following ethical approval by the Animal Care and Use Committee of Shanghai Tenth People's Hospital, Tongji University School of Medicine, this study was carried out following the Regulations of Experimental Animal Administration. Wild-type C57BL/6J mice (8 months old) of both sexes (20 females, and 20 male, with 5 males and 5 females in each group) were placed under a reversed $12 \mathrm{~h} / 12 \mathrm{~h}$ light/dark cycle at 20 $22^{\circ} \mathrm{C}$ for a period of 1 week before the experiments in Shanghai Laboratory Animal Center, Chinese Academy of Sciences, Shanghai, China. At random, each mouse in the treatment group (10 mice; with 5 males and 5 females) received an intraperitoneal injection of 5 $\mathrm{mg} / \mathrm{kg}$ NaHS (Cat \#: 161527, Sigma-Aldrich, St
Louis, MO, US) while each mouse in the control group (10 mice; with 5 males and 5 females) received injection of $0.1 \mathrm{ml}$ saline. The dosage of $\mathrm{NaHS}$ used was based on previous studies, which showed that $5 \mathrm{mg} / \mathrm{kg}$ for rats would have desirable results [28-32]. Thirty minutes after $\mathrm{NaHS}$ or saline dose, the mice were exposed to $1.4 \%$ isoflurane in $100 \% \mathrm{O}_{2}$ for $2 \mathrm{hr}$, using a home-made chamber. Isoflurane concentration was verified, and adjusted when needed using a gas analyzer (GE Healthcare, MA, USA). All animals were consistently kept at $37 \pm 0.5^{\circ} \mathrm{C}$ during the experiments.

Fear conditioning test was carried out as described previously [15], with slight modifications using a standard chamber from Stoelting (Wood Dale, IL, USA). On the first day after isoflurane, mice were habituated for $3 \mathrm{~min}$ before the presentation of the auditory tone $(60$ $\mathrm{s}, 3600 \mathrm{~Hz}, 80 \mathrm{~dB})$. In the final 2 seconds of the tone, mice received gentle foot shock (0.8 mA, $0.5 \mathrm{sec})$ through the floor grid. After the foot shock, mice were kept in the testing chamber for 30 seconds before sending to the home cage. On the second day, mice first received a context test (without any stimulus). Two hours later, a tone test was carried out. Briefly, mice were placed in a novel context (distinct wall color and odor) for $3 \mathrm{~min}$ before the presentation of the tone for $3 \mathrm{~min}$. During the context and tone experiments, the time during which the mice exhibited freezing behavior (failure to make any movement except respiration) was noted and evaluated with an Any-Maze video tracking system with the following settings: first, freezing on threshold for $10 \mathrm{sec}$ and then freezing off threshold for $20 \mathrm{sec}$ and last minimum freezing duration for mere $1 \mathrm{sec}$ ). The chamber was cleaned with $75 \%$ ethanol after each session.

\section{In vitro Experiments}

The in vitro experiments were carried out with human neuroglioma cellsH4 with transfection of human amyloid precursor protein (H4-APP cells, a gift from Dr. Zhongcong Xie at the Massachusetts General Hospital, Boston, MA, USA) [15]. Cells were maintained in high-glucose Dulbecco's modified Eagle's medium (Lonza, $M D, U S A)$ with 9 percent heat-inactivated fetal calf serum (Atlanta Biologicals, GA, USA), 100 $\mu \mathrm{g} / \mathrm{mL}$ streptomycin, $2 \mathrm{mM}$ L-glutamine (G1146, Sigma-Aldrich, MO, USA), $100 \mathrm{U} / \mathrm{ml}$ penicillin, and $220 \mu \mathrm{g} / \mathrm{mL}$ G418 (Corning Mediatech, Manassas, VA, USA) at $37{ }^{\circ} \mathrm{C}$ in humid atmosphere having $21 \% \quad \mathrm{O}_{2}$ and $5 \% \mathrm{CO}_{2}$. Cells were treated with $\mathrm{NaHS}$ (final concentration: 100 $\mu \mathrm{M})$ or vehicle in 6 -well plates at $1 \times 10^{6}$ cells in $1.5 \mathrm{~mL}$ as described previously, and 30 min prior 
to isoflurane exposure (2\%). MPTP opening, MMP, and ATP levels were examined 3 hours later; caspase-3 activation and ROS were examined 6 hours later, as detailed in previous study [15]. A Datex infrared gas analyzer was adopted to closely observe isoflurane concentration during the exposure (PuritanBennett, Tewksbury, MA, USA).

\section{Western blot assay}

Cells were lyzed using a buffer containing 150 $\mathrm{mM} \mathrm{NaCl}, 10 \mathrm{mM}$ Tris- $\mathrm{HCl}, 0.5 \%$ Nonidet P-40, 2 $\mathrm{mM}$ EDTA, $1 \mu \mathrm{g} / \mathrm{mL}$ leupeptin, $1 \mu \mathrm{g} / \mathrm{mL}$ aprotinin, and $1 \mu \mathrm{g} / \mathrm{mL}$ pepstatin $A$ [15]. Lysate obtained was then centrifuged at $2500 \times \mathrm{g}$ for $15 \mathrm{~min}$ and the supernatant was probed using a polyclonal rabbit-anti-mouse anti-caspase-3 antibody (Cat \#: 9662, 1:1100; Cell Signaling Technology, MA, USA) that recognizes the full-length (35-40 kDa) and 17-20 kDa caspase-3. Anti-rabbit IgG (\#7074, 1:5000; Cell Signal Technology) was used as secondary antibody. An enhanced chemiluminescence method (Thermo Fisher, USA) was employed and then analyzed on $\mathrm{NIH}$ ImageJ (US National Institutes of Health, USA). The results obtained were normalized with the $\beta$ actin control. Protein concentration was measured using a bicinchoninic method. All experiments were done six times and the mean was reported.

\section{ROS measurement}

ROS concentration was measured using OxiSelect Intracellular ROS Kit and an OxiSelect In Vitro ROS/RNS Kit (Cell Biolabs, CA, USA) as described previously [15]. The fluorescence value was maintained at $480 / 530 \mathrm{~nm}$.

\section{Isolation of mitochondria}

Active Motif kit (Carlsbad, CA, USA) was used to isolate the mitochondria. Cell homogenate and the supernatant were centrifuged at $800 \times g$ and $10,000 \times \mathrm{g}$, at $4^{\circ} \mathrm{C}$ for $20 \mathrm{~min}$ to obtain the mitochondrial (pellet) and a cytosolic fraction (supernatant), respectively [33].

\section{Mitochondrial swelling}

Mitochondrial swelling was examined as previously described $[33,34]$. The mitochondria preparation (protein concentration: $0.5 \mathrm{mg} / \mathrm{ml}$ ) was placed in a buffer containing $10 \mathrm{mM}$ TrisMops (pH 7.4), $125 \mathrm{mM} \mathrm{KCl,} 1 \mathrm{mM} \mathrm{KH}_{2} \mathrm{PO}_{4}, 2.5$ $\mathrm{mM}$ malate, $5 \mathrm{mM}$ glutamate, and $10 \mu \mathrm{M}$ EGTATris ( $\mathrm{pH} \mathrm{7.4)} \mathrm{for} 5$ min with or without adding 1 $\mu \mathrm{M}$ cyclosporine A. Time-dependent absorbance change at $540 \mathrm{~nm}$ in mitochondrial suspensions from isoflurane or control groups was examined using a Beckman DU 640 spectrophotometer (Beckman, CA, USA).

\section{Evaluation of MMP}

Mitochondrial membrane potential (MMP) was estimated through tetraethylbenzimidazolylcarbocyanine iodides (JC-1) fluorescence ratio detection and tetramethylrhodamine ethyl ester and perchlorate (TMRE). JC-1 MMP detection kit (30001, Biotium, CA, USA) were used as described previously [15]. MMP was calculated as the ratio of red fluorescence to green fluorescence by fluorometric plate reader (Thermo Fisher Scientific, MA, USA). For measuring MMP by TMRE, cells were treated and evaluated under a $100 \times$ objective lens fluorescence microscope (BZ 9000, Keyence, Itasca, IL, USA).

\section{ATP measurement}

ATP (A22066 Invitrogen, CA, USA) concentration was examined as described previously [15]. Briefly, to calculate the ATP, fluorescence was measured and compared with a curve obtained from samples of known ATP.

\section{Data analysis}

Data are presented as mean values $\pm S D$ and analysed using ANOVA and post-hoc Bonferroni as appropriate. At $95 \%$ confidence interval, $p<0.05$ was regarded to be statistically significant.

\section{RESULTS}

\section{NaHS ameliorates cognitive impairment induced by isoflurane}

FC tests showed that mice in isoflurane group had decreased freezing time to context (Figure 1A) $(F=12.027, P<0.0001)$ and to tone (Figure 1B) $(F=6.482, P=0.004)$ compared to control group. Decreased freezing time suggests that the isoflurane induced the cognitive deficit. Furthermore, in the isoflurane NaHS group, the decreased freezing time was alleviated compared to isoflurane group (Figure 1A-B).

\section{NaHS inhibits Caspase- 3 activitycaused by isoflurane}

WB showed increased caspase- 3 fragments, but not full-length caspase-3, upon isoflurane exposure $(p=0.034)$ (Figure 2). NaHS attenuated the increase of caspase-3 fragments induced by isoflurane $(p=0.046)$ but did not affect caspase- 
A

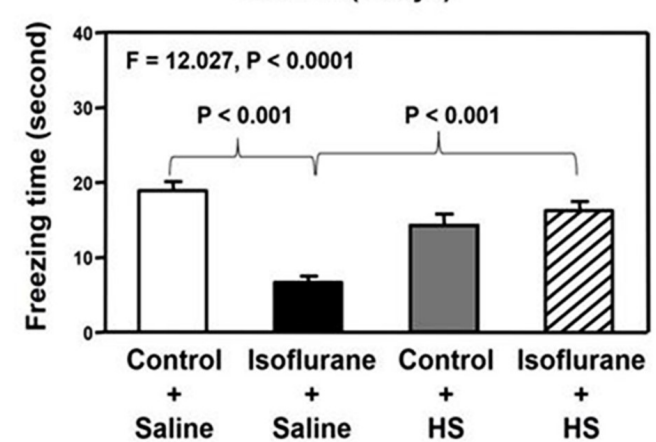

B

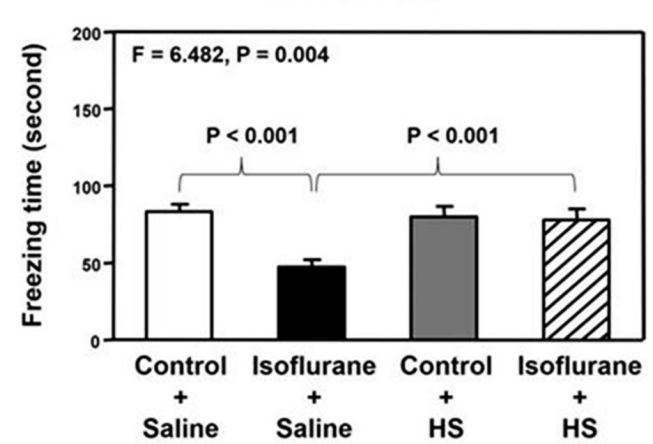

Figure 1: NaHS ameliorates isoflurane-induced cognitive impairment.

A: Results of the FCT context test in mice treated with control conditions plus saline, isoflurane $(1.4 \%)$ plus saline, control conditions plus NaHS (5 mg/kg) and isoflurane (1.4\%) plus NaHS (5 mg/kg) for $2 \mathrm{~h}$. B: Results of the FCT tone test in mice treated with control conditions plus saline, isoflurane $(1.4 \%)$ plus saline, control conditions plus NaHS (5 mg/kg) and isoflurane (1.4\%) plus NaHS (5 mg/kg). The two-way ANOVA and a post hoc Bonferroni test were used to analyze the results

A

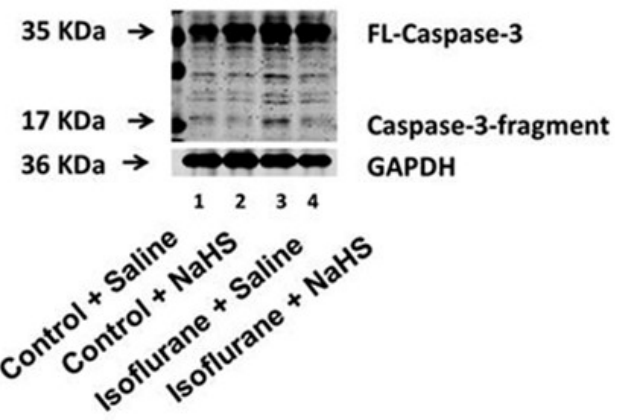

B

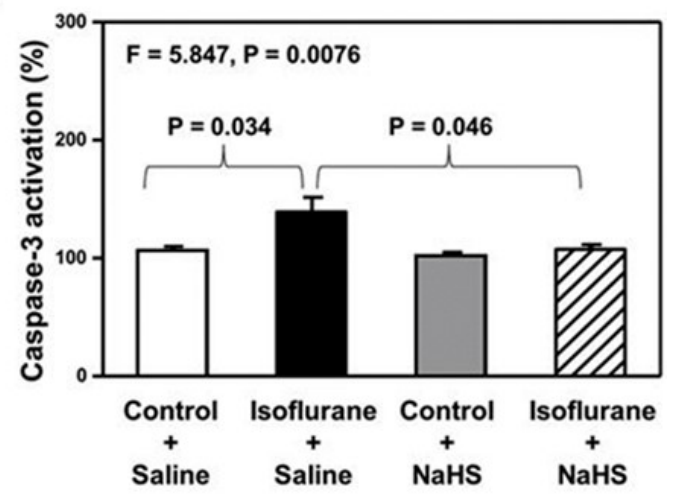

Figure 2: NaHS attenuates isoflurane-induced caspase-3 activation in H4-APP cells.

A: Western blot showing caspase-3 activation after 6-h exposure to $2 \%$ isoflurane (lane 3 ) versus the control (lane 1), and the effect of 100- $\mu \mathrm{M}$ NaHS (lane 4) in H4-APP cells. GAPDH was used as a loading control. B: Statistical summary of the Western blot data. $N=6$ per group. FL: full length.

3 fragment in cells not exposed to isoflurane. Isoflurane and $\mathrm{NaHS}$ had significant interaction $(F=5.847, p=0.0076)$.

\section{NaHS attenuates ROS increase induced by isoflurane}

Isoflurane and NaHS had a significant effect on ROS level $(F=34.12, p<0.001)$ (Figure 3). $\mathrm{NaHS}$ attenuated the increase in isofluraneinduced ROS level $(p<0.001)$ and decreased ROS in cells not exposed to isoflurane $(p<$ $0.001)$.

\section{NaHS attenuates isoflurane-induced mPTPs opening}

$\mathrm{Ca}^{2+}$ induced significant mitochondria swelling in isoflurane-exposed cells $(p<0.01) \quad \mathrm{NaHS}$ attenuated $\mathrm{Ca}^{2+}$-induced mitochondria swelling and permeability transition $(P<0.01$ for isoflurane) but did not affect mitochondria swelling in cells not exposed to isoflurane (Figure $4)$.

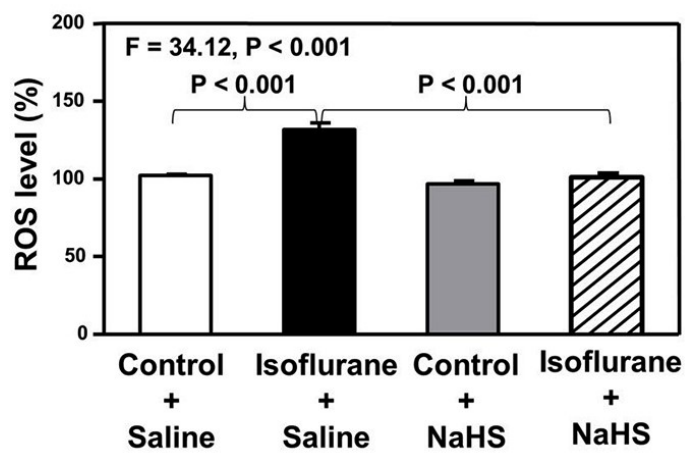

Figure 3: NaHS attenuates isoflurane-induced ROS accumulation in H4-APP cells. Fluorescence staining for ROS showing the effect $6-h$ exposure to $2 \%$ versus the control, and the effect of 100- $\mu$ M NaHS. ROS: reactive oxygen species 


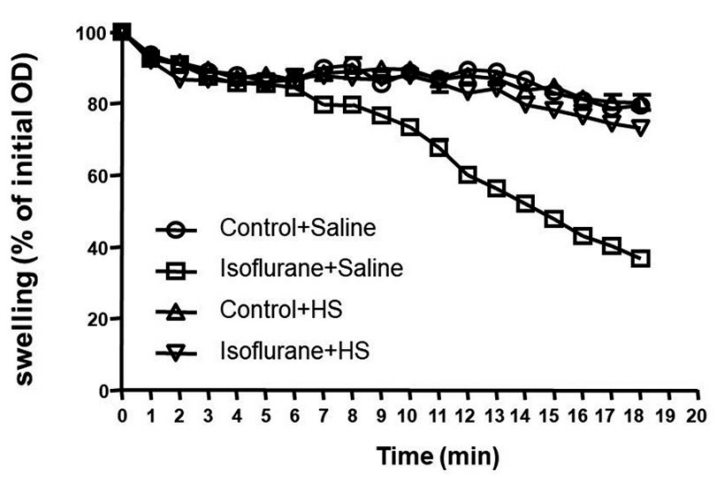

Figure 4: NaHS attenuates isoflurane-induced opening of mPTPs. Opening of MPTPs was assessed by measuring mitochondrial swelling. Data are represented as the relative percentage to the control $O D$ at $540 \mathrm{~nm}$ absorbance plotted against time. Bars indicate the standard deviation of six experiments

\section{NaHS attenuates isoflurane-induced MMP reduction}

TMRE showed decrease in MMP in isoflurane group compared to control (Figure 5A). NaHS attenuated isoflurane-induced reduction in the MMP which was confirmed by the JC-1 fluorescence ratio (Figure 5B). Isoflurane and NaHS interacted significantly $(F=18.16, p<$ 0.01) (Figure 5B)

\section{NaHS attenuates isoflurane-induced ATP reduction}

A significant interaction was observed between isoflurane and $\mathrm{NaHS}(\mathrm{F}=7.128, p=0.0046)$ (Figure 6). The post-hoc Bonferroni analysis suggested isoflurane decreased ATP $(p=0.009)$ inhibited by NaHS $(p=0.024)$.

\section{DISCUSSION}

The FCT results demonstrate that NaHS could mitigate isoflurane-induced cognitive impairment. An experiment in cultured cells showed that $\mathrm{NaHS}$ mitigated caspase- 3 activation induced by isoflurane, ROS accumulation, ATP reduction, and mitochondrial dysfunction. This may be the first study showing NaHS could inhibit isofluranemediated cytotoxicity whose underlying mechanism of reduced cytotoxicity could be attributed to suppression of isoflurane-induced ROS accumulation, ATP reduction, and mitochondrial malfunction.

Oxidative stress often results in different neurodegenerative diseases. It was reported that $\mathrm{H}_{2} \mathrm{~S}$ provides protection to primary neurons and immortalized mouse hippocampal cells from
A

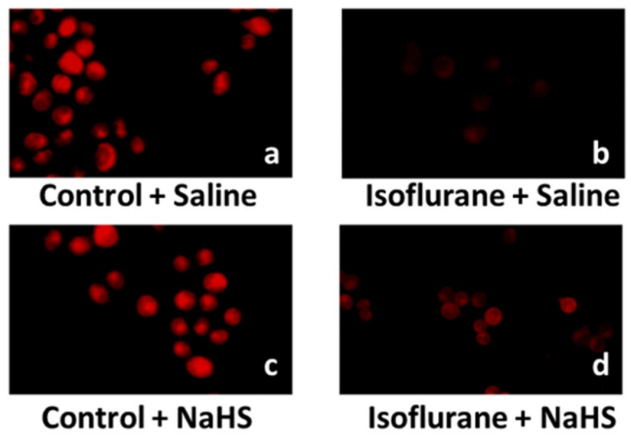

B

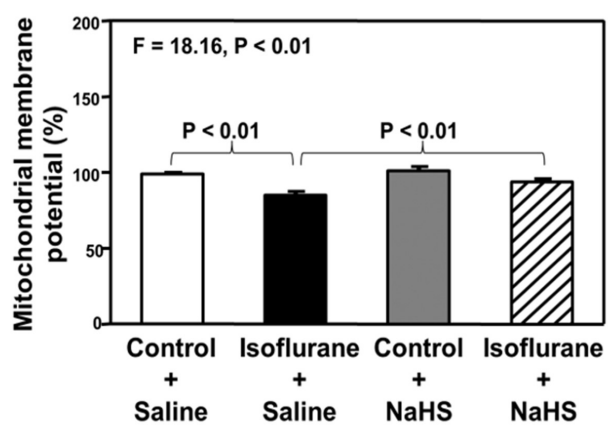

Figure 5: NaHS attenuates the isoflurane-induced reduction in mitochondrial membrane potential (MMP) in H4-APP cells. A. Tetramethylrhodamine ethyl ester and perchlorate staining showing the effect of 3-h exposure to $2 \%$ isoflurane versus the control, and the effect of 100- $\mu M$ NaHSin H4-APP cells. $N=6$ per group. B. Tetraethylbenzimidazolylcarbocyanine iodide (JC-1) fluorescence analysis showing the effect of 3-h exposure to $2 \%$ isoflurane versus the control, and the effect of 100- $\mu \mathrm{M}$ NaHSin H4-APP cells. $N=6$ per group

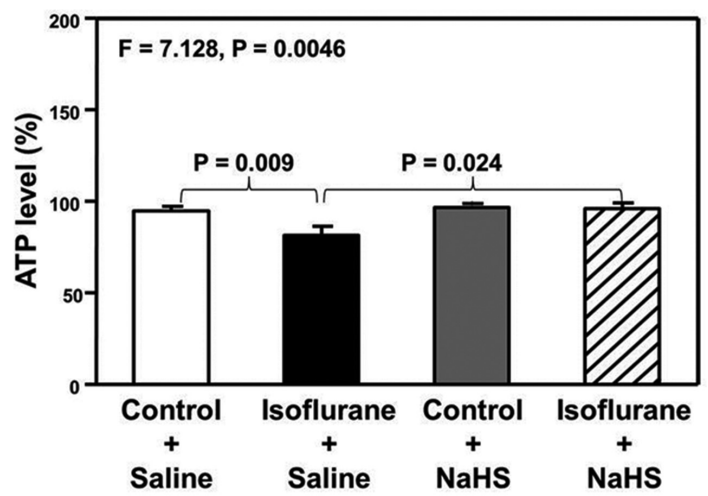

Figure 6: NaHS attenuates the isoflurane-induced reduction in ATP levels in H4-APP cells. Bioluminescence assay showing the effect of 3-h exposure to $2 \%$ isoflurane versus the control, and the effect of 100- $\mu M$ NaHSin H4-APP cells. $N=6$ per group.

oxidative glutamate toxicity [19,22]. Additionally, $\mathrm{Lu}$ et al. discovered that $\mathrm{H}_{2} \mathrm{~S}$ enhances glutamate uptake and increases glutathione 
production to prevent excessive glutamate accumulation in synaptic clefts, thus protecting astrocytes from oxidative toxicity [23]. Similarly, our findings indicate that $\mathrm{NaHS}$ could attenuate ROS accumulation in cells induced by isoflurane, suggesting that $\mathrm{NaHS}$ could mitigate the oxidative toxicity of isoflurane.

The mPTP opening decreases the potential of the membrane and releases apoptogenic proteins to amplify the apoptotic mechanism [3538]. Oxidative and other cellular stresses cause mPTP opening [39]. In contrast, inhibition of $\mathrm{mPTP}$ opening protects neurons from apoptosis [34]. $\mathrm{Hu}$ et al. have shown that $\mathrm{H}_{2} \mathrm{~S}$ inhibits apoptosis by rotenone in SH-SY5Ycells by protecting mitochondria [21]. Xie et al. proposed that MPTP opening and MMP reduction contribute to caspase-3 activation by isoflurane, which can be attenuated by a hydrogen-rich saline $[15,39]$. Our findings are consistent with these findings as they show that NaHS inhibited isoflurane-induced MPTP opening, and thus attenuated caspase-3 promotion by isoflurane. These results supported the notion that caspase3 promoted by isoflurane involved mitochondrial dysfunction and ROS mechanisms.

Our FCT experiments in mice demonstrated that NaHS could attenuate cognitive impairment caused by isoflurane exposure. This finding encourages future investigation of $\mathrm{NaHS}$ as a treatment for neurobehavioral decline induced by anesthesia. Various behavior studies have shown that $\mathrm{H}_{2} \mathrm{~S}$ could ameliorate cognitive and memory impairments by attenuating ROS production and the activation of apoptotic pathways. Previous studies using Morris maze test showed that $\mathrm{H}_{2} \mathrm{~S}$ (i.e., $\mathrm{NaHS}$ ) or Spropargylcysteine (SPRC), could ameliorate lipopolysaccharide-induced cognitive impairment $[28,40]$. Chu et al. showed that NaHS could alleviate memory impairment in mice due to surgery [30]. A study using $A \beta$ rat models of $A D$ showed that NaHS could attenuate spatial memory impairment [29]. He et al. demonstrated that NaHS improved memory acquisition and spatial learning in APP/PS1 transgenic mice [25]. Altogether, these results indicated that exogenous $\mathrm{H}_{2} \mathrm{~S}$ could attenuate cognitive dysfunction due to a variety of etiological factors.

First important limitation of this study was that we did not examine the dose-response relationship as $\mathrm{Yin}$ et al. showed that $\mathrm{NaHS}$ protected from I/R injury by regulating oxidative stress in a dosedependent manner (e.g., 0.2 and $0.4 \mu \mathrm{mol} / \mathrm{kg}$ ) [41]. It is possible that, at different doses, NaHS may have distinct or even opposing effect on caspase-3 activity induced by isoflurane, ROS, mitochondria, and ATP. Second, the behavioral effects of NaHS were examined using only FCT. Third, we did not check the potential functions of different $\mathrm{H}_{2} \mathrm{~S}$ donors (e.g. SPRC). Effects of $\mathrm{H}_{2} \mathrm{~S}-$ releasing agents with sustained and controlled release that more faithfully mimic physiological conditions are essential. Despite these limitations, the present study showed that NaHS could attenuate cognitive impairments induced by isoflurane exposure.

\section{CONCLUSION}

This study indicated that NaHS could ameliorate isoflurane-induced cognitive impairments, likely through attenuating caspase- 3 activation induced by isoflurane, mPTP opening, ROS increase, and MMP reduction. Future studies using other $\mathrm{H}_{2} \mathrm{~S}$ donors (e.g., SPRC) and other anesthetics (e.g., sevoflurane) are warranted.

\section{DECLARATIONS}

\section{Acknowledgement}

Financial support and sponsorship: this work was supported by the National Natural Science Foundation of China (81600921) to Cheng Li, Natural Science Foundation of Shanghai (16ZR1426400) to Cheng Li.

\section{Conflict of interest}

No conflict of interest is associated with this study.

\section{Contribution of authors}

We declare that this work was done by the authors named in this article and all liabilities pertaining to claims relating to the content of this article will be borne by the authors. $X Z$ and $C L$ designed and contributed equally this work. DC, $Y F, L Z, X Y N, X S$ and $X Z N$ collected data while $D C$ wrote the manuscript which was read and approved for submission by all authors.

\section{Open Access}

This is an Open Access article that uses a funding model which does not charge readers or their institutions for access and distributed under the terms of the Creative Commons Attribution License (http://creativecommons.org/licenses/by/ 4.0) and the Budapest Open Access Initiative (http://www.budapestopenaccessinitiative.org/rea d), which permit unrestricted use, distribution, and reproduction in any medium, provided the original work is properly credited. 


\section{REFERENCES}

1. Alzheimer's Association. 2016 Alzheimer's disease facts and figures. Alzheimers Dement 2016; 12: 459-509.

2. Bilotta F, Qeva E, Matot I. Anesthesia and cognitive disorders: a systematic review of the clinical evidence. Expert Rev Neurother 2016; 16: 1311-1320.

3. Liu Y, Pan N, Ma Y, Zhang S, Guo W, Li H, Zhou J, Liu $G$, Gao M. Inhaled sevoflurane may promote progression of amnestic mild cognitive impairment: a prospective, randomized parallel-group study. Am J Med Sci 2013; 345: 355-360.

4. Chen CW, Lin CC, Chen KB, Kuo YC, Li CY, Chung CJ. Increased risk of dementia in people with previous exposure to general anesthesia: a nationwide population-based case-control study. Alzheimers Dement 2014; 10: 196-204.

5. Bratzke LC, Koscik RL, Schenning KJ, Clark LR, Sager MA, Johnson SC, Hermann BP, Hogan KJ. Cognitive decline in the middle-aged after surgery and anaesthesia: results from the Wisconsin Registry for Alzheimer's Prevention cohort. Anaesthesia 2018; 73: 549-555.

6. Sprung J, Jankowski CJ, Roberts RO, Weingarten TN, Aguilar AL, Runkle KJ, Tucker AK, McLaren KC, Schroeder DR, Hanson AC, Knopman DS, Gurrieri C, Warner DO. Anesthesia and incident dementia: a population-based, nested, case-control study. Mayo Clin Proc 2013; 88: 552-561.

7. Knopman DS, Petersen RC, Cha RH, Edland SD, Rocca WA. Coronary artery bypass grafting is not a risk factor for dementia or Alzheimer disease. Neurology 2005; 65: 986-990

8. Avidan MS, Searleman AC, Storandt $M$, Barnett $K$, Vannucci A, Saager L, Xiong C, Grant EA, Kaiser D, Morris JC, Evers AS. Long-term cognitive decline in older subjects was not attributable to noncardiac surgery or major illness. Anesthesiology 2009; 111: 964-970.

9. Xie Z, Culley DJ, Dong Y, Zhang G, Zhang B, Moir RD, Frosch MP, Crosby G,Tanzi RE. The common inhalation anesthetic isoflurane induces caspase activation and increases amyloid beta-protein level in vivo. Ann Neurol 2008; 64: 618-627.

10. Xie Z, Dong Y, Maeda U, Alfille P, Culley DJ, Crosby G, Tanzi RE. The commoninhalation anesthetic isoflurane induces apoptosis and increases amyloid betaprotein levels. Anesthesiology 2006; 104: 988-994.

11. Xie Z, Dong Y, Maeda U, Moir RD, Xia W, Culley DJ, Crosby G, Tanzi RE. The inhalation anesthetic isoflurane induces a vicious cycle of apoptosis and amyloid beta-protein accumulation. J Neurosci 2007; 27: 1247-1254.

12. Eckenhoff RG, Johansson JS, Wei H, Carnini A, Kang B, Wei W, Pidikiti R, Keller JM, Eckenhoff MF. Inhaled anesthetic enhancement of amyloid-beta oligomerization and cytotoxicity. Anesthesiology 2004; 101: 703-709.

13. Brambrink AM, Evers AS, Avidan MS, Farber NB, Smith $D J$, Zhang $X$, Dissen GA, Creeley CE, Olney JW. Isoflurane-induced neuroapoptosis in the neonatal rhesus macaque brain. Anesthesiology 2010; 112: 834-841.

14. Ni C, Li C, Dong Y, Guo X, Zhang Y, Xie Z. Anesthetic isoflurane induces DNAdamage through oxidative stress and p53 pathway. Mol Neurobiol 2017; 54: 3591-3605.

15. Zhang $Y, X u Z$, Wang $H$, Dong $Y$, Shi HN, Culley DJ, Crosby G, Marcantonio ER, Tanzi RE, Xie Z. Anesthetics isoflurane and desflurane differently affect mitochondrial function, learning, and memory. Ann Neurol 2012; 71: 687-698.

16. Xie L, Yu S, Yang K, Li C, Liang Y. Hydrogen sulfide inhibits autophagicneuronal cell death by reducing oxidative stress in spinal cord ischemiareperfusion injury. Oxid Med Cell Longev 2017; 2017: 8640284.

17. Ma S, Zhong D, Ma P, Li G, Hua W, Sun Y, Liu N, Zhang $L$, Zhang $W$. Exogenoushydrogen sulfide ameliorates diabetes-associated cognitive decline by regulating the mitochondria-mediated apoptotic pathway and IL-23/IL17 expression in db/dbmice. Cell Physiol Biochem 2017; 41: 1838-1850.

18. Yu Q, Wang $B$, Zhao T, Zhang $X$, Tao L, Shi J, Sun $X$, Ding Q. NaHS protects against the impairments induced by oxygen-glucose deprivation in different agesof primary hippocampal neurons. Front Cell Neurosci 2017; 11: 67.

19. Kimura $Y$, Kimura $H$. Hydrogen sulfide protects neurons from oxidative stress. FASEB J 2004; 18: 1165-1167.

20. Hu X, Luan L, Guan W, Zhang S, Li B, Ji W, Fan H. Hydrogen sulfide attenuates isoflurane-induced neuroapoptosis and cognitive impairment in the developing rat brain. BMC Anesthesiol 2017; 17: 123.

21. Hu LF, Lu M, Wu ZY, Wong PT, Bian JS. Hydrogen sulfide inhibits rotenone-induced apoptosis via preservation of mitochondrial function. Mol Pharmacol 2009; 75: 27-34.

22. Kimura Y, Dargusch R, Schubert D, Kimura H. Hydrogen sulfide protects HT22 neuronal cells from oxidative stress. Antioxid Redox Signal 2006; 8: 661-670.

23. Lu M, Hu LF, Hu G, Bian JS. Hydrogen sulfide protects astrocytes against $H(2) \mathrm{O}(2)$-induced neural injury via enhancing glutamate uptake. Free Radic Biol Med 2008; 45: 1705-1713.

24. Tang YY, Wang AP, Wei HJ, Li MH, Zou W, Li X, Wang $C Y$, Zhang $P$, Tang $X Q$. Role of silent information regulator 1 in the protective effect of hydrogen sulfide onhomocysteine-induced cognitive dysfunction Involving reduction of hippocampal ERstress. Behav Brain Res 2018; 342: 35-42.

25. He XL, Yan N, Zhang H, Qi YW, Zhu LJ, Liu MJ, Yan Y. Hydrogen sulfide improves spatial memory impairment and decreases production of Abeta in APP/PS1 transgenic mice. Neurochem Int 2014; 67: 1-8.

26. Sarukhani M, Haghdoost-Yazdi H, Sarbazi Golezari A, Babayan-Tazehkand A, Dargahi T, Rastgoo N. Evaluation of the antiparkinsonism and neuroprotective effects of hydrogen sulfide in acute 6hydroxydopamine-induced animal model of Parkinson's disease: behavioral, histological and biochemical studies. Neurol Res 2018; 1-9.

27. Kumar M, Modi M, Sandhir R. Hydrogen sulfide attenuates homocysteine-induced cognitive deficits and neurochemical alterations by improving endogenous hydrogensulfide levels. Biofactors 2017; 43: 434-450.

28. Gong $Q H$, Wang $Q$, Pan LL, Liu XH, Huang H, Zhu YZ. Hydrogen sulfide attenuates lipopolysaccharideinduced cognitive impairment: a pro-inflammatory pathway in rats. Pharmacol Biochem Behav 2010; 96 : 52-58.

29. Xuan A, Long D, Li J, Ji W, Zhang M, Hong L, Liu J. Hydrogen sulfide attenuates spatial memory impairment and hippocampal neuroinflammation in beta-amyloid rat model of Alzheimer's disease. J Neuroinflammation 2012; 9: 202.

30. Chu QJ, He L, Zhang W, Liu CL, Ai YQ, Zhang Q. Hydrogen sulfide attenuates surgical trauma-induced inflammatory response and cognitive deficits in mice. $J$ Surg Res 2013; 183: 330-336.

31. Fan $H$, Guo $Y$, Liang $X$, Yuan $Y$, Qi X, Wang M, Ma J, Zhou $H$. Hydrogen sulfide protects against amyloid beta-peptide induced neuronal injury via attenuating inflammatory responses in a rat model. J Biomed Res 2013; 27: 296-304.

32. Wang Z, Zhan J, Wang X, Gu J, Xie K, Zhang Q, Liu D. Sodium hydrosulfide prevents hypoxia-induced behavioral impairment in neonatal mice. Brain Res 
2013; 1538: 126-134.

33. Du H, Guo L, Fang F, Chen D, Sosunov AA, McKhann GM, Yan Y, Wang C, Zhang H, Molkentin JD, GunnMoore FJ, Vonsattel JP, Arancio O, Chen JX, Yan SD. Cyclophilin $D$ deficiency attenuates mitochondrial and neuronal perturbation and ameliorates learning and memory in Alzheimer's disease. Nat Med 2008; 14: 1097-1105.

34. Schinzel AC, Takeuchi O, Huang Z, Fisher JK, Zhou Z, Rubens J, Hetz C, Danial NN, Moskowitz MA, Korsmeyer SJ. Cyclophilin $D$ is a component of mitochondrial permeability transition and mediates neuronal cell death after focal cerebral ischemia. Proc Natl Acad Sci U S A 2005; 102: 12005-12010.

35. Halestrap A. Biochemistry: a pore way to die. Nature 2005; 434: 578-579.

36. Crompton M. Mitochondria and aging: a role for the permeability transition? Aging Cell 2004; 3: 3-6.

37. Halestrap AP, McStay GP, Clarke SJ. The permeability transition pore complex: another view. Biochimie 2002; 84: 153-166.

38. Baines CP, Kaiser RA, Purcell NH, Blair NS, Osinska H,
Hambleton MA, Brunskill EW, Sayen MR, Gottlieb RA, Dorn GW, Robbins J, Molkentin JD. Loss of cyclophilin $D$ reveals a critical role for mitochondrial permeability transition in cell death. Nature 2005; 434: 658-662.

39. Li C, Hou L, Chen D, Lin F, Chang T, Li M, Zhang L, Niu $X$, Wang $H$, Fu S, Zheng J. Hydrogen-rich saline attenuates isoflurane-induced caspase-3 activation and cognitive impairment via inhibition of isofluraneinduced oxidative stress, mitochondrial dysfunction, and reduction in ATP levels. Am J Transl Res 2017; 9: $1162-1172$.

40. Gong QH, Wang Q, Pan LL, Liu XH, Xin H, Zhu YZ. Spropargyl-cysteine, a novel hydrogen sulfidemodulated agent, attenuates lipopolysaccharideinduced spatial learning and memory impairment: involvement of TNF signaling and NF-kappaB pathway in rats. Brain Behav Immun 2011; 25: 110-119.

41. Yin J, Tu C, Zhao J, Ou D, Chen G, Liu Y, Xiao X. Exogenous hydrogen sulfide protects against global cerebral ischemia/reperfusion injury via its antioxidative, anti-inflammatory and anti-apoptotic effects in rats. Brain Res 2013; 1491: 188-196. 